\title{
A Study on the Characteristics of Palm-Based Polyurethane as a Lightweight Aggregate in Concrete Mix
}

(Kajian terhadap Sifat Poliuretana Sawit sebagai Agregat Ringan dalam Campuran Konkrit)

\author{
KAMARUL AINI MOHD SARI, SOHIF MAT, KHAIRIAH HAJI BADRI* \\ \& MUHAMMAD FAUZI MOHD ZAIN
}

\begin{abstract}
ASTRACT
Research on the development of lightweight concrete (LWC) utilizing wastes and natural resources as lightweight aggregates (LWA) is increasingly gaining attention worldwide due to sustainable and environmental concerns. A new alternative is using palm kernel oil polyol (PKO-p)-based polyurethane (PU) as filler. Rigid PU is a block copolymer comprised of a monomeric PKO-p and 2, 4-methylene diphenyl diisocyanate (crude MDI). The property of PKO-p, its ratio with crude MDI and reaction time were determined. The reaction time showed the average of $60 \mathrm{~s}$ for cream time and $95 \mathrm{~s}$ for rise time with maximum hardening time of 8 min. The reaction between PKO-p to MDI at 1:1 ratio resulted in a very short hardening time (within $2 \mathrm{~min}$ ). The compressive strength of the rigid PU was at $7.0 \mathrm{MPa}$ at a density of $206 \mathrm{~kg} / \mathrm{m}^{3}$. Further increase in the amount of PKO-p increased the density and compressive strength of the PU. PU aggregate in the concrete mixture was added at 1 to $5 \%(w / w)$ to obtain concrete with density of less than 1800 $\mathrm{kg} / \mathrm{m}^{3}$. The resulting concrete has excellent compressive strength $(17.5 \mathrm{MPa})$ and thermal conductivity $(0.24 \mathrm{~W} / \mathrm{m} \cdot \mathrm{K})$. The results showed that physical properties of PU played the most significant effect on the physical and mechanical properties of the lightweight concrete.
\end{abstract}

Keywords: Concrete mix; lightweight aggregate; palm kernel oil polyol; rigid polyurethane

ABSTRAK

Penyelidikan dalam membangunkan konkrit ringan (LWC) menggunakan bahan buangan dan sumber semula jadi sebagai agregat ringan (LWA) semakin mendapat perhatian dunia disebabkan oleh faktor kelestarian bahan dan kebimbangan terhadap alam sekitar. Satu alternatif baru dalam menghasilkan poliuretana (PU) sebagai pengisi adalah dengan menggunakan bahan berasaskan minyak isirung sawit (PKO). Poliuretana tegar adalah blok kopolimer yang mengandung $i$ poliol PKO (PKO-p) dan 2,4-difenilmetana diisosianat (MDI mentah). Sifat PKO-p, nisbahnya kepada MDI dan masa tindak balasnya ditentukan. Masa tindak balas menunjukkan purata masa masing-masing 60 dan 90 s untuk masa pengkriman dan masa menaik dengan masa pematangan maksimum 8 min. Tindak balas antara PKO-p dengan MDI pada nisbah 1:1 menunjukkan masa pematangan yang singkat (2 min). Kekuatan mampatan PU tegar adalah 7.0 MPa pada ketumpatan $206 \mathrm{~kg} / \mathrm{m}^{3}$. Penambahan PKO-p meningkatkan ketumpatan dan kekuatan mampatan PU. Jumlah agregat PU halus dalam campuran konkrit ditambah daripada 1 hingga 5\% (b/b) untuk mencapai ketumpatan konkrit kurang daripada $1800 \mathrm{~kg} /$ $\mathrm{m}^{3}$. Konkrit ringan yang dihasilkan sangat baik daripada segi kekuatan mampatan (17.5 MPa) dan kekonduksian terma $(0.24 \mathrm{~W} / \mathrm{m} \cdot \mathrm{K})$. Keputusan menunjukkan bahawa sifat fizikal PU menunjukkan kesan paling ketara ke atas sifat fizikal dan mekanik konkrit ringan.

Kata kunci: Agregat ringan; campuran konkrit; poliol minyak isirung sawit; poliuretana tegar

\section{INTRODUCTION}

Concrete is a widely used and highly in demand construction material in civil engineering especially for buildings and bridges, due to its strength and durability. It can be manufactured from a great number of materials, in many ways for various applications. Concrete can be classified into three broad categories based on density and compressive strength. The term lightweight concrete (LWC) is used for concrete with density less than $1800 \mathrm{~kg} / \mathrm{m}^{3}$ and compressive strength of $18 \mathrm{MPa}$ compared to $30 \mathrm{MPa}$ for normal weight concrete (NWC) with density of $2400 \mathrm{~kg} / \mathrm{m}^{3}$. Heavy weight concrete (HWC), used for radiation shielding, is a high density concrete of $3200 \mathrm{~kg} / \mathrm{m}^{3}$ in density and strength of 60 MPa (Mehta 2006).

The high demand for concrete using normal weight aggregates (NWAs), such as gravel has significantly reduced the natural resources and smashed up the environment. The replacement from NWA to lightweight aggregates (LWA) gives an opportunity for researchers to study the waste and natural resources widely available in Malaysia. LWC can be produced by introducing LWA: gassing agents such as aluminum powder or foaming agents; lightweight mineral aggregate such as perlite, vermiculite, pumice, slate and clay; or plastic granules as aggregate, e.g. expanded 
polystyrene (EPS), polyurethane (PU) or other polymeric materials (Chandra \& Berntsson 2003; Fraj et al. 2001; Kan \& Demirboga 2009).

Being the largest palm oil producer in the world, Malaysia has approximately 426 palm oil mills, processing 99.85 million tons of fresh fruit bunch per year and producing an estimated 91.2 million tons of crop residue per year in the form of empty fruit bunch, fiber and shell (Abdullah \& Sulaiman 2013). Generally, there are studies on LWA in the production of LWC such as oil palm kernel shell (OPKS) (Alengaram \& Jumaat 2013; Mannan \& Ganapathy 2001; Shafigh et al. 2010), coconut shell (Gunasekaran et al. 2011; Yerramala \& Ramachandrudu 2012), kenaf (Akil \& Omar 2011; Khalil et al. 2010), empty fruit bunch (EFB) (Jawaid at al. 2011; Kolop et al. 2010), expanded polystyrene (EPS) (Bakri et al. 2007; Kan \& Demirboga 2007; Laukaitis et al. 2005; Madandoust et al. 2011; Yi et al. 2012) and polyurethane (PU) (Demharter 1996; Mounanga et al. 2008).

Petrochemical resources are used extensively worldwide in the chemical industry particularly for EPS and PU productions. These sources are getting limited and depleting. They are also experiencing price instability. In PU industry, polyols and isocyanates are two major ingredients used and both are derived from petroleum. Vegetable oil and fat are alternative sources for polyols. Vegetable oils, like soya bean oil, sunflower oil, palm oil, olive oil and linseed oil with a worldwide production of about 127 million tons in 2007, are used mainly in food applications (76\%), while $19.5 \%$ account for technical applications and $1.5 \%$ for other applications (Ismail et al. 2006).

This study presents the usage of natural, renewable and sustainable materials namely palm kernel oil polyol (PKO-p), as a substitute to petroleum-based polyols in the polyurethane industry. Badri (2011) had successfully produced and developed palm-based polyurethane for wide applications, such as rigid foam, elastomer, coating, adhesive and sealant. The usage of palm-based PU in the concrete mix has not been reported elsewhere. The PU system consists of PKO-p and 2, 4-methylene diphenyl diisocyanate (crude MDI). Polyisocyanate acts as the polymerising agent to the polyol. Thus, urethane and related foams are recognised as building block polymers (Ashida 2007).

The objective of this study was to establish the performance of new concrete composite using palm-based polyurethane as filler and its applicability as the construction building material thus, improving the properties of the concrete.

\section{MATERIALS AND METHODS}

The PKO-p was processed in the pilot plant at MPOB Bangi Lama, Malaysia following method by Badri (2011). The preparation of PU foam was conducted by reacting PKO-p with crude MDI (2, 4-methylene diphenyl diisocyanate) from Cosmopolyurethane (M) Sdn Bhd, Malaysia. Commercial Portland cement with brand name 'Orang Kuat' (YTL Cement Bhd, Kuala Lumpur, Malaysia) was used as the main raw material for the concrete mix. This cement fulfilled the requirement specified by MS 522: Part 1: 2003/2007 standard. Commercial river sand with particle size of $5 \mathrm{~mm}$ following BS882: 1983 standard was used. The lightweight aggregate, LWA used was rigid polyurethane (PU) that has been ground and sieved to particle size of $5 \mathrm{~mm}$ (Kan \& Demirboga 2009; Mounanga et al. 2008).

PU foam was prepared via addition polymerization between PKO-p and crude MDI (as the hardener) as shown in Figure 1. The mixture was stirred using a mechanical stirrer at $1000 \mathrm{rpm}$ for $10 \mathrm{~s}$. The mixture was then poured into a screw-tight mold and was allowed to cure for 10 min. The ratio of PKO-p resin to MDI was optimized prior to identifying the density and the stage of reaction, as shown in Table 1. During polymerization, the reaction time namely cream time (Agubra et al. 2013), rise time (RT) and hardening time (HT) (Ashida 2007) were observed and recorded. Once demolded the PU foam was let to condition at room temperature for $16 \mathrm{~h}$ before further characterizations.

PU fine aggregate was obtained by grinding technique using a granulator and sieved to particle size of $5 \mathrm{~mm}$. The yellowish particle was granular, rough and grainy

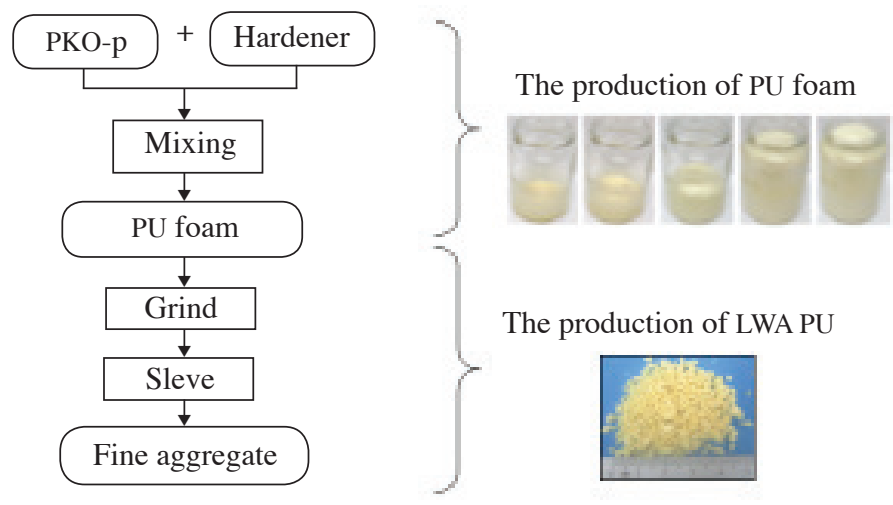

FIGURE 1. The production of LWA from palm-based PU 
TABLE 1. Optimization of PKO-p to MDI ratio

\begin{tabular}{ccccccc}
\hline \multirow{2}{*}{ Sample } & \multicolumn{2}{c}{ PU ratio } & CT & RT & HT & Density \\
\cline { 2 - 7 } & PKO-p & MDI & $(\mathrm{s})$ & $(\mathrm{s})$ & $(\mathrm{s})$ & $\left(\mathrm{kg} / \mathrm{m}^{3}\right)$ \\
\hline CC01 & 50 & 50 & 70 & 86 & 240 & 206 \\
PY12 & 54.5 & 45.4 & 64 & 99 & 330 & 225 \\
PY14 & 58.3 & 41.6 & 62 & 102 & 483 & 266 \\
PY16 & 61.5 & 38.5 & 63 & 96 & 0 & 0 \\
PY18 & 35.7 & 64.3 & 65 & 90 & 0 & 0 \\
PY20 & 66.6 & 33.3 & 66 & 100 & 0 & 0 \\
MD12 & 45.4 & 54.5 & 62 & 94 & 136 & 196 \\
MD16 & 38.5 & 61.5 & 65 & 104 & 122 & 214 \\
MD20 & 33.3 & 66.6 & 69 & 80 & 120 & 234 \\
\hline
\end{tabular}

*CT: Cream Time, RT: Rise Time, HT: Hardening Time

in texture. Mounanga et al. (2008) utilized PU particles at a density of $40 \mathrm{~kg} / \mathrm{m}^{3}$. Two categories of aggregates were used, that were coarse aggregates $(8-20 \mathrm{~mm})$ as lightweight aggregate in concrete and fine aggregates $(0-8 \mathrm{~mm})$ as lightweight aggregate in mortars. Akcay and Tasdemir (2006), Fraj et al. (2001) and Gadea et al. (2010) studies on lightweight mortar made with recycled PU foam waste using fine particle with size ranging between 0 and $4 \mathrm{~mm}$ and coarse particles with size ranging between 8 and $20 \mathrm{~mm}$.

The production of lightweight concrete (LWC) filled with palm-based PU was carried out as shown in Figure 2. The PU-filled LWC was prepared by initially integrating cement, sand and water in a drum mixer. Ground PU was then added at $0-5 \%(\mathrm{w} / \mathrm{w})$ loading and further stirred until a homogeneous concrete mix was obtained. The mix was molded in a steel mold and demolded after $24 \mathrm{~h}$. Three specimens were tested at each curing time of 7, 14 and 28 days to obtain the average compressive stress and load peak data.

\section{OPTIMIZATION}

The formulation developments determine the end properties of the desired products, at least to its minimum.
Two mix proportions were investigated: The ratio of PU (PKO-p to MDI) and the loading percentage of ground PU in the concrete mix. Table 1 shows the analyzed data in determining the optimum PKO-p to MDI ratio. Nine samples were prepared, where CC01 was the control, PY with additional of PKO-p and MD with extra MDI. Table 2 shows the composition of LWC mix following CC01 ratio and PU loading at $0-5 \% \mathrm{w} / \mathrm{w}$. Three attempts on water per cement $(\mathrm{w} / \mathrm{c})$ ratio were also studied at $0.5,0.6$ and $0.7 \mathrm{w} / \mathrm{c}$. David et al. (2013) and FIP Manual of Lightweight Aggregate Concrete (1983) reported that most LWCs retain, absorb, and release considerably more water than normal weight aggregates. This is water retained (from w/c ratio) in the pores of the aggregate.

\section{CHARACTERIZATIONS}

\section{DENSITY}

The foam density was determined following BS4370: Part 1: 1988 Method 2 (Method of test for rigid cellular materials: Determination of apparent density) and applying the equation of mass, $\mathrm{kg}$ divided by volume, $\mathrm{m}^{3}$. The foam samples were prepared by molding technique into cubes of $50 \times 50 \times 50 \mathrm{~mm}$ in dimension. Three replicates were used

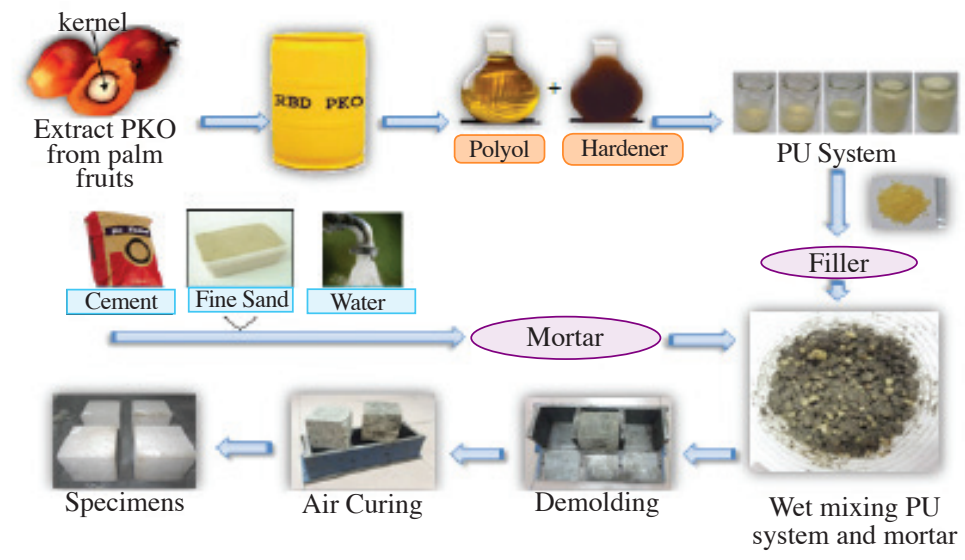

FIGURE 2. The production of LWC filled with PU 
TABLE 2. Concrete mix proportion

\begin{tabular}{ccccc}
\hline Sample & Cement: Sand & w/c & $\%$ PU & Density $\left(\mathrm{kg} / \mathrm{m}^{3}\right)$ \\
\hline K0 & $1: 2$ & 0.5 & 0 & 1996 \\
K1 & & & 1 & 1815 \\
K2 & & & 2 & 1740 \\
K3 & & 3 & 1435 \\
K4 & & 4 & 1301 \\
K5 & 0.6 & 5 & 1169 \\
L0 & & 0 & 1789 \\
L1 & & 1 & 1752 \\
L2 & & 2 & 1591 \\
L3 & & 3 & 1557 \\
L4 & & 4 & 1485 \\
L5 & 0.7 & 5 & 1368 \\
M0 & & 0 & 1855 \\
M1 & & 1 & 1844 \\
M2 & & 2 & 1686 \\
M3 & & 3 & 1527 \\
M4 & & 4 & 1512 \\
M5 & & 5 & 1475 \\
\hline
\end{tabular}

and carefully weighed using an analytical balance. The dimensions were measured following BS4370: Part 1: 1988 Method 1B (Method of test for rigid cellular materials: Measurement of dimension), using a digital vernier caliper.

\section{FOURIER TRANSFORM INFRARED SPECTROSCOPY ANALYSIS}

A Perkin Elmer FT-IR spectrophotometer was used to verify the functional groups present in the PU chain. The scanning was carried out at wave numbers ranged from 4000 to 650 $\mathrm{cm}^{-1}$ using DATR (Diamond Attenuation Total Reflectance) technique. The presence of amine $(\mathrm{NH})$, carbonyl $(\mathrm{C}=\mathrm{O})$ urethane, carbamate $(\mathrm{CNH})$ and $\mathrm{COC}$ peaks was determined to verify the formation of PU.

\section{COMPRESSIVE STRENGTH}

The compression test for polyurethane was conducted according to BS 4370: Part 1: 1988: Method 3 (Method of test for rigid cellular materials: Compression test). The samples were cut to a dimension of $50 \times 50 \times 50 \mathrm{~mm}$ (length $\times$ width $\times$ thickness). The test was carried out using Instron Universal Testing Machine model 5566 at a cross-head speed of $50 \mathrm{~mm} / \mathrm{min}$ until the thickness reduced to $10 \%$ of its original thickness. The compressive stress and modulus were recorded as average of five specimens.

The compressive strength test for lightweight concrete was conducted according to BS EN 12390: Part 3: 2002 (Testing for hardened concrete: Compressive strength of test specimens). The test was carried out using Autocon 2000 Universal Testing Machine with a loading rate of $7.0 \mathrm{kN} / \mathrm{s}$. Three specimens were prepared by molding technique into a cubic mold of $100 \times 100 \times 100 \mathrm{~mm}$ in dimensions. They were tested based on exposure time of 7, 14 and 28-days. The compressive stress and load peak data were recorded.
THERMAL CONDUCTIVITY

The thermal conductivity was conducted using the Heat Flow Meter HFM 436 Lambda following ASTM C518 (Standard Test Method for Steady-State Thermal Transmission Properties by Means of the Heat Flow Meter Apparatus). Each sample of rigid PU foam and lightweight concrete was prepared by molding technique using a thick plate of size $300 \times 300 \times 25 \mathrm{~mm}$ and analyzed at three different temperatures of 20,38 and $50^{\circ} \mathrm{C}$.

\section{RESULTS AND DISCUSSION}

\section{PALM-BASED POLYURETHANE}

Polyurethane can be produced through the reaction between polyhydroxyl compound (polyol) and diisocyanates (MDI) as shown below:

$$
\begin{aligned}
& \text { Polyol }+ \text { Diisocyanates } \longrightarrow \quad \text { Polyurethane }
\end{aligned}
$$

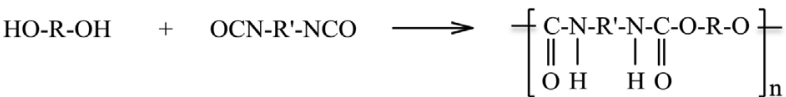

Polyurethane is a block copolymer containing segments of low molecular weight polyester or polyether bonded to a urethane group (-NHCOO). Generally, a polyether or polyester will produce soft segments, whereas MDI in the urethane bond forms hard segments. Polyurethane is formed through an exothermic reaction between polyhydroxyl compounds with two or more reactive hydroxyl (-OH) groups per molecule (diols, triols and polyols) and isocyanates that have more than one reactive isocyanate group (-NCO) per molecule (diisocyanates, polyisocyanates) (Ashida 2007; Badri 2012; Woods 1990). 
Data in Table 1 was used to determine the optimum ratio in reacting PKO-p and MDI. Additional amount of PKO-p in the PU system (PY12 to PY14) increased the density and compressive strength of the rigid PU. However, at higher amount of PKO-p (PY16-PY20) the product formed tacky compound indicating an incomplete reaction. There was unreacted PKO-p left as residual. Brittle PU foam was observed at higher level of MDI. The reaction between MDI and PKO-p produces polyurethane but when MDI is in excess, there are greater tendency that MDI reacts with other substances such as water condensate and MDI itself to form urea and isocyanurate, respectively.

The reaction time recorded during polymerization is tabulated in Table 1. After $10 \mathrm{~s}$ of mixing, the average of cream time and rise time were 60 and $95 \mathrm{~s}$, respectively, with maximum hardening time of $8 \mathrm{~min}$. Hence, the optimized ratio is CC01 with PKO-p to MDI at 1:1 ratio. The hardening time was within $2 \mathrm{~min}$.

Density The palm-based PU obtained was a high-density rigid PU with density ranging from 196 to $409 \mathrm{~kg} / \mathrm{m}^{3}$. The maximum compressive strength was $11.4 \mathrm{MPa}$. The compression strength of the PU increased with increasing density. This however, affects the thermal conductivity of the LWC (Jones \& MacCarthy 2005; Nambiar \&
Ramamurthy 2006). In this study, CC01 with $1: 1$ ratio of the PKO-p to MDI with an average density of $206 \mathrm{~kg} / \mathrm{m}^{3}$ was selected as the lightweight aggregate.

FTIR Spectroscopy The reaction between PKO-p and MDI forms a polymer with urethane backbone $(\mathrm{NHC}(\mathrm{O}) \mathrm{O})$. Figure 3 shows the FTIR spectrum of the PU foam. The presence of amide (NH) group (Badri et al. 2010; Makal \& Waynne 2005; Su'ait et al. 2014), carbonyl urethane group $(-\mathrm{C}=\mathrm{O})$ and carbamate group $(\mathrm{CNH})$ in the FTIR spectrum confirmed the formation of the urethane linkages in the PU. The summarized data as tabulated in Table 3 shows the carbonyl peak $(\mathrm{C}=\mathrm{O})$ and amide peak were identified at $1730 \mathrm{~cm}^{1}$ and $3323 \mathrm{~cm}^{1}$, respectively. The carbamate vibration peak was observed at $1598 \mathrm{~cm}^{1}$. There was no traces of the $-\mathrm{NCO}$ peak (at $2270 \mathrm{~cm}^{-1}$ ) indicated that MDI has completely reacted with PKO-p during the addition polymerization (Badri et al. 2010).

Compressive Strength Six attempts of varying PU ratio labeled as CC01, PY12, PY14, MD12, MD16 and MD20 were studied to determine the compressive strength of rigid PU following BS 4370:Part 1:1988: Method 3. Figure 4 shows the effect of varying the ratio of PKO-p to MDI on the compressive strength of the rigid PU. The compressive

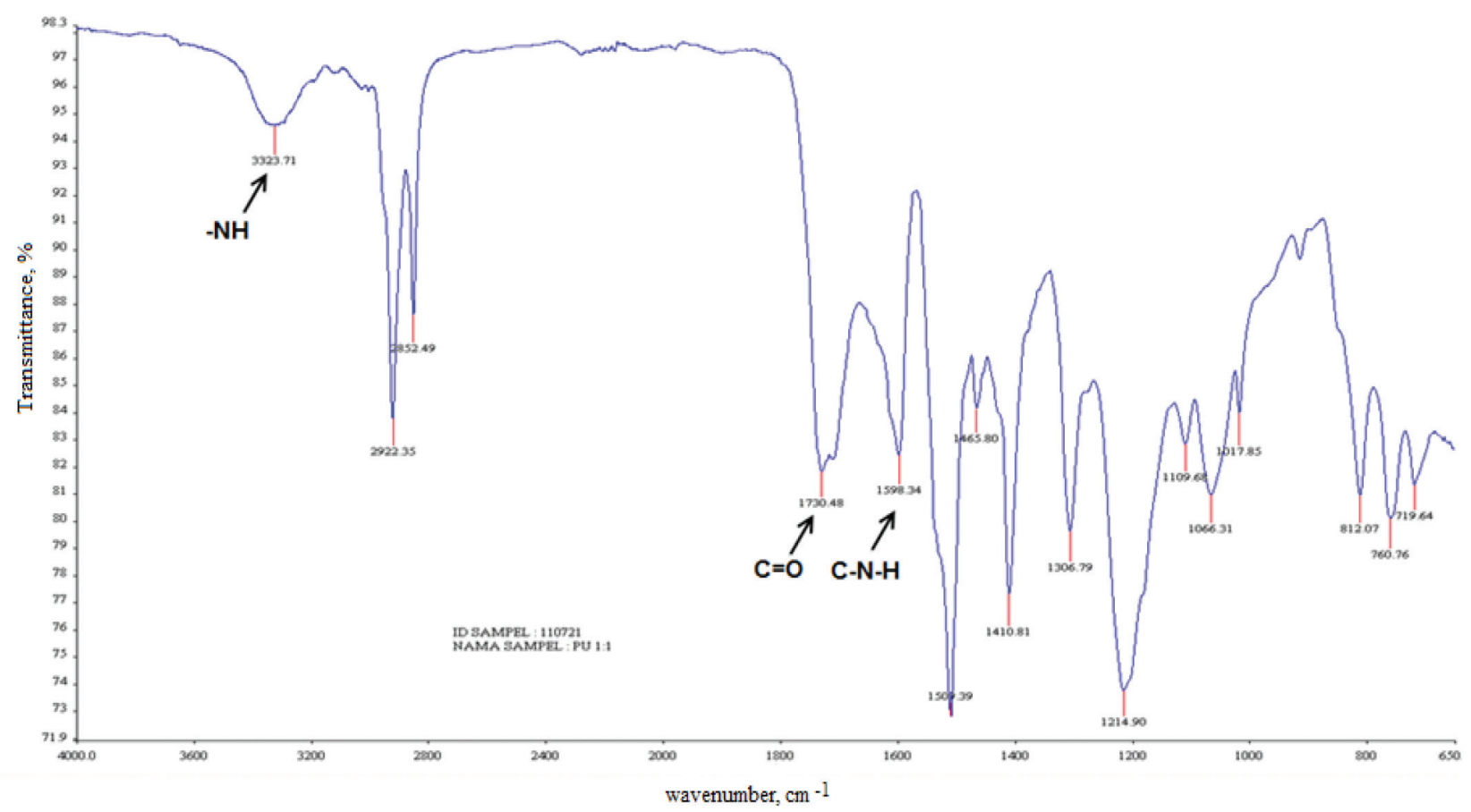

FIGURE 3. FTIR spectrum of the CC01PU foam at 1:1 ratio of PKO-p to MDI

TABLE 3. FTIR characteristic peaks for polyurethane

\begin{tabular}{cc}
\hline Peak assignments & Wave number $\left(\mathrm{cm}^{-1}\right)$ \\
\hline $\mathrm{N}-\mathrm{H}$ & 3323 \\
$\mathrm{C}=\mathrm{O}$ & 1730 \\
$\mathrm{C}-\mathrm{N}-\mathrm{H}$ & 1598 \\
\hline
\end{tabular}


strength of the PU with an increasing amount of PKO-p was from 7.0 to $11.5 \mathrm{MPa}$ while at an increasing amount of MDI was from 7.0 to $4.4 \mathrm{MPa}$. These results showed that the strength of palm-based PU was affected by PU ratio and density. The selected ratio of 1:1 (CC01) produced PU foam with a density of $206 \mathrm{~kg} / \mathrm{m}^{3}$ with compressive strength of $7 \mathrm{MPa}$. The strength of the PU is depending on the degree of crosslinking which is much related to the ratio of PKO-p to MDI.

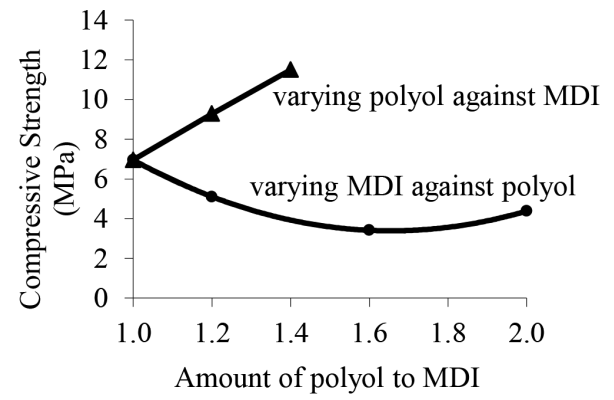

FIGURE 4. The effect of PKO-p to MDI ratio on the compressive strength of rigid $\mathrm{PU}$

\section{LIGHTWEIGHT CONCRETE}

Density Figure 5 shows the effects of palm-based PU loading and water to cement ratio $(\mathrm{w} / \mathrm{c})$ on the density of the lightweight concrete. The investigated $\mathrm{w} / \mathrm{c}$ ratios were $0.5,0.6$ and 0.7 at 0 to $5 \%(\mathrm{w} / \mathrm{w})$ PU particles. This resulted in the density of approximately between 1200 and 1850 $\mathrm{kg} / \mathrm{m}^{3}$. By increasing the amount of PU in the concrete mix from 1 to $5 \%(\mathrm{w} / \mathrm{w})$, the density decreased from 22 to $35 \%$. In addition, a low-density concrete was obtained by lowering the w/c ratio with trend as shown in Figure 6. This was due to the formation of dehydrated mixture and low workability. On the other hand, increasing the percentage of PU loading would also dehydrate the concrete mix and this weakens the interaction between PU particles and the mortar. Nevertheless, it is important to understand that although PU is a hydrophobic material, its porous structure creates the absorption effect of water in the surrounding to diffuse internally and acts like a hydrophilic material physically. Both hydrophilic and hydrophobic types of PU can be used in the concrete technology to stop water, but hydrophobic systems are best suited for permanent repair of most leaking basement cracks (Emecole 2014). Makal and Waynne (2005) described dry polyurethane coatings as more hydrophobic when exposed to water and more hydrophilic upon drying. Therefore, to resolve the factors which influence the compressive strength and thermal conductivity, the w/c ratio was optimized to obtain a mixture with good workability (Saman et al. 2005). Thus, $0.6 \mathrm{w} / \mathrm{c}$ ratio and $3 \%(\mathrm{w} / \mathrm{w})$ PU loading were selected to produce lightweight concrete less than 1800 $\mathrm{kg} / \mathrm{m}^{3}$ as specified by Chandra and Berntsson (2003). This formulation was a homogeneous, highly workable and easy-to cast composition.

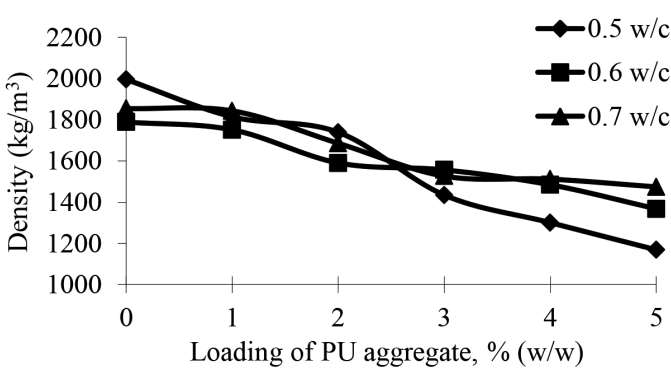

FIGURE 5. The effect of palm-based PU loading on the density of the lightweight concrete at varying $\mathrm{w} / \mathrm{c}$ ratios

Compressive Strength The compressive strength of PUfilled LWC specimen was tested at 7, 14 and 28 days. Figure 6 shows the result for control and palm-based lightweight concrete. The results discovered optimal proportion at $3 \%(\mathrm{w} / \mathrm{w})$ PU loading attaining the compressive strength from 11.3 to $17.5 \mathrm{MPa}$. The strength increased upon prolongs exposure and gradually increased after 28 days to approximately $35 \%$. This result exhibited that the compressive strength of the PU-filled LWC is a function of time. Apparently, the strength of lightweight concrete is sufficient to formulate a structural concrete in accordance to the minimum strength requirement. The ACI 213R-8 guide for structural lightweight aggregate concrete defines structural LWC as those having a 28-day compressive strength of more than $17.0 \mathrm{MPa}$ and air-dried density not exceeding $1850 \mathrm{~kg} / \mathrm{m}^{3}$.

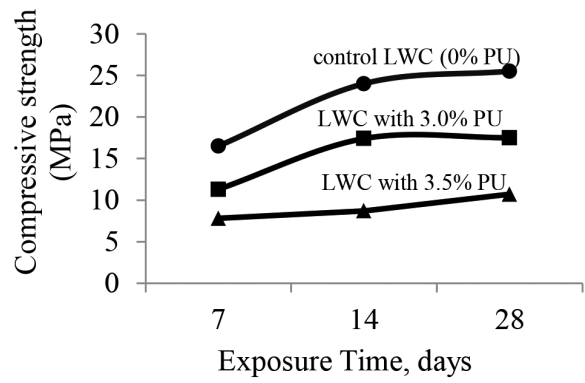

FIGURE 6. Effect of varying PU addition in the lightweight concrete on the compressive strength

Thermal Conductivity nductivity value of $3 \%$ palmbased PU-filled LWC $(\lambda=0.241 \mathrm{~W} / \mathrm{m} \cdot \mathrm{K})$ was lower than normal concrete $(\lambda=1.700 \mathrm{~W} / \mathrm{m} \cdot \mathrm{K})$ as reported by other researchers (Kim et al. 2012). According to Badri et al. (2004), the thermal conductivity of a water-blown rigid PU was achievable at $0.025 \mathrm{~W} / \mathrm{m} \cdot \mathrm{K}$ with density ranging from 10 to $50 \mathrm{~kg} / \mathrm{m}^{3}$. However, in this study, the rigid PU produced was a high-density PU foam and thus the $\lambda$ value was determined at $0.051 \mathrm{~W} / \mathrm{m} \cdot \mathrm{K}$. Inclusion of PU as the filler contributes to a lower k-value $(\lambda)$, indicating an excellent thermal insulation performance for the lightweight concrete. 


\section{CONCLUSION}

A new alternative of lightweight aggregate from an inexpensive, renewable and sustainable natural resource was investigated. This LWA was the palm-based PU synthesized from the palm-based polyol (PKO-p). A one to one ratio of PKO-p to MDI was selected as the optimum reactant ratio of rigid polyurethane foam. The density was higher than $200 \mathrm{~kg} / \mathrm{m}^{3}$ but excellent in compressive strength (7.0-11.5 MPa). The FTIR results verified the presence of polyurethane. The properties of the structural lightweight concrete was enhanced by loading of $3 \% \mathrm{w} / \mathrm{w}$ polyurethane aggregate with $0.6 \mathrm{w} / \mathrm{c}$ ratio in the mortar mixture. At this proportion, the LWC achieved density of $1557 \mathrm{~kg} / \mathrm{m}^{3}$ and compressive strength of $17.5 \mathrm{MPa}$. The compressive strength result exceeded the minimum compressive strength of $17.0 \mathrm{MPa}$ based on ACI 213R-8: Structural lightweight aggregate concrete. The inclusion of palm-based PU improved the thermal conductivity of the LWC.

\section{ACKNOWLEDGEMENTS}

The authors wish to thank Universiti Kebangsaan Malaysia for the grant No. UKM-GUP-2011-158 under Solar Energy Research Institute (SERI), UKM-GUP-2012-042 under Polymer Research Center (PORCE), Faculty of Science and Technology as well as 03-01-02-SF0949 from Ministry of Science, Technology and Innovation (MOSTI), Malaysia on the funding of this project. High appreciations to Universiti Tun Hussein Onn Malaysia and Ministry of Education, Malaysia for the sponsorship of the principal researcher.

\section{REFERENCES}

Abdullah, N. \& Sulaiman, F. 2013. Chapter 3: The oil palm wastes in Malaysia. In Biomass Now-Sustainable Growth and Use, edited by Matovic, M.D. New York: InTech Publication.

Agubra, V.A., Owuor, P.S. \& Hosur, M.V. 2013. Influence of nanoclay dispersion methods on the mechanical behavior of E-Glass/Epoxy nanocomposites. Nanomaterials 3(3): 550-563.

Akcay, B. \& Tasdemir, M.A. 2006. Measuring, monitoring and modeling concrete properties. In Effects of Lightweight Aggregates on Autogenous Deformation in Concrete, edited by Konsta-Gdoutos, M.S. Netherland: Springer Netherland.

Akil, H.M. \& Omar, M.F. 2011. Kenaf fiber reinforced composites: A review. Journal of Materials and Design 32(8): 4107-4121.

Alengaram, U.J. \& Jumaat, M.Z. 2013. Utilization of oil palm kernel shell as lightweight aggregate in concrete: A review. Journal of Construction and Building Materials 38: 161-172.

Ashida, K. 2007. Polyurethane and Related Foams: Chemistry and Technology. London: Taylor \& Francis.

Badri, K.H. 2012. Biobased polyurethane from palm kernel oil-based polyol. In Polyurethane, edited by Fahmina Zafar \& Eram Sharmin. Croatia: InTech Publishing. pp. 447-470.

Badri, K.H. 2011. Process for the Production of Vegetable Oil-based Polyurethane Polyols. MyIPO. Malaysia. MY 145094-A.

Badri, K.H., Wong, C.S., Shahrom, M.S.R., Liow, C.T., Yuhana, N. \& Norzali, N.R.A. 2010. FTIR spectroscopy analysis of the prepolymerization of palm-based polyurethane. Journal of Solid State Science and Technology 18(2): 1-8.

Badri, K.H.,Zakaria, O. \& Ahmad, S.H. 2004. Rigid polyurethane foams from oil palm resources. Journal of Materials Science 39: 5541-5542.

Bakri,A.M.M.A., Ruzaidi, G.C.M., Norazian, M.N., Kamarudin, H. \& Abu Bakar, M.D. 2007. Preliminary study on concrete with polystyrene waste coarse aggregate. CIRAIC (Construction Industry Research Achievement in the Construction Industry). CIDB. pp. 64-67.

Chandra, S. \& Berntsson, L. 2003. Lightweight Aggregate Concrete: Science, Technology and Application. New York: Noyes Publications.

David, P.M., Zimmer, A.S., Bolduc, M.J. \& Hopps, E.R. 2013 Is Lightweight Concrete All Wet? Structure magazine. U.S.: Copper Creek Companies, Inc.

Demharter, A. 1996. Polyurethane rigid foam, a proven thermal insulating material for applications between $+130^{\circ} \mathrm{C}$ and $-196^{\circ} \mathrm{C}$. Journal of Cryogenics 38: 113-117.

Emecole, Inc. 2014. Use of Hydrophobic and Hydrophilic Polyurethane Foams for Crack Injection. http://www. emecole.com/pages/Use-of-Hydrophobic-and-HydrophilicPolyurethane-Foams-for-Crack-Injection.html.

FIP Manual of lightweight Aggregate Concrete. 1983. Int. Organization for the Development of Structural Concrete. New York: John Wiley and Sons.

Fraj, A.B., Kismi, M. \& Mounanga, P. 2001. Volarization of coarse rigid polyurethane foam waste in lightweight aggregate concrete. Journal of Construction and Building Materials 24: 1069-1077.

Gadea, J., Rodrigues, A., Campos, P.L., Garabito, J \& \& Calderon, V. 2010.Lightweight mortar made with recycled polyurethane foam. Journal of Cement \& Concrete Composites 32: 672677.

Gunasekaran, K., Kumar, P.S. \& Lakshmipathy, M. 2011. Mechanical and bond properties of coconut shell concrete. Journal of Construction and Building Materials 25(1): 92-98.

Ismail, T.N.M.T., Satar, M.N., Soi, H.S., Hassan, H.A., Lye, O.T. \& Ahmad, S. 2006. Palm-based Rigid Polyurethane Foams. MPOB Information Series June TT No 343.

Jawaid, M., Khalil, H.P.S.A., Bhat, A.H. \& Abu Baker, A. 2011. Impact properties of natural fiber hybrid reinforced epoxy composites. Journal of Advanced Materials Research 264265: 688-693.

Jones, M.R. \& MacCarthy, A. 2005. Behaviour and assessment of foamed concrete for construction applications. In Use of Foamed Concrete in Construction, edited by Dhir, R.K., Newlands, M.D. \& McCarthy, A. London: Thomas Telford. pp 61-88.

Kan, A.K. \& Demirboga, R. 2009. A novel material for lightweight concrete production. Journal of Cement \& Concrete Composites 31: 489-495.

Kan, A.K. \& Demirboga, R. 2007. Effect of cement and EPS beads ratios on compressive strength and density of lightweight concrete. Indian Journal of Engineering \& Materials Sciences 14: 158-162.

Khalil, H.P.S.A., Yusra, A.F.I., Bhat, A.H. \& Jawaid, M. 2010 Cell wall ultrastructure, anatomy, lignin distribution and chemical composition of Malaysian cultivated kenaf fiber. Industrial Crops and Products 31: 113-121.

Kim, H.K., Jeon, H.J. \& Lee, H.K. 2012. Workability and mechanical, acoustic and thermal properties of liightweight aggregate concrete with a high volume of entrained air. Journal of Construction and Building Materials 29: 193-200. 
Kolop, R., Ibrahim, W.H. \& Eng, J.E. 2010. Properties of cement blocks containing high content of oil palm empty fruit bunches (EFB) fibers. International Conference on Civil Engineering 2008. UMP: UMP Publisher.

Laukaitis, A., Zuraukast, R. \& Keriene, J. 2005. The effect of foam polystyrene granules on cement composite properties. Journal of Cement \& Concrete Composites 27: 41-47.

Madandoust, R., Ranjbar, M. \& Mousavi, S.Y. 2011. An investigation on the fresh properties of self-compacted lightweight concrete containing expanded polystyrene. Journal of Construction and Building Materials 25: 37213731.

Makal, U. \& Wynne, K.J. 2005. Water induced hydrophobic surface. Langmuir 21(9): 3742-3745.

Mannan, M.A. \& Ganapathy. C. 2001. Mix design for oil palm shell concrete. Journal of Cement \& Concrete Research 31(9): 1323-1325.

Mehta, P.K. \& Monteiro, P.J. 2006. Concrete: Microstructure, Properties and Materials. New York: McGraw-Hill.

Mounanga, P., Gebongbon, W., Poullain, P. \& Turcry, P. 2008. Proportioning and characterization of lightweight concrete mixtures made with rigid polyurethane foam wastes. Journal of Cement \& Concrete Composites 30: 806-814.

Nambiar, E.K. \& Ramamurthy, K. 2006. Influence of filler type on the properties of foam concrete. Journal of Cement \& Concrete Composites 28: 475-480.

Saman, H.M., Ibrahim, A., Ridzuan, A.R.M. \& Kamaruddin, K. 2005. Optimization of foamed concrete mix of different sand-cement ratio and curing conditions. In Use of Foamed Concrete in Construction, edited by Dhir, R.K., Newlands, M.D. \& McCarthy, A. London: Thomas. pp. 37-44.

Shafigh, P., Jumaat, M.Z. \& Mahmud, H. 2010. Mix design and mechanical properties of oil palm shell lightweight aggregate concrete: A review. Journal of the Physical Sciences 5(14): 2127-2134.

Su'ait, M.S., Ahmad, A., Badri, K.H., Mohamed, N.S., Rahman, M.Y.A., Azanza Ricardo, C.L. \& Scardi, P. 2014. The potential of polyurethane bio-based solid polymer electrolyte for dye-sensitized solar cell application. International Journal of Hydrogen Energy 39: 3005-3017.
Woods, G. 1990. The ICI Polyurethane Book. New York: John Wiley \& Sons.

Yerramala,A.\& Ramachandrudu,C. 2012. Properties of concrete with coconut shells as aggregate replacement. International Journal of Engineering Inventions 1(6): 21-31.

Yi, X., Jiang, L., Xu, J. \& Li, Y. 2012. Mechanical properties of expanded polystyrene lightweight aggregate concrete and brick. Journal of Construction and Building Materials 27: $32-38$.

Kamarul Aini Mohd Sari \& Sohif Mat

Faculty of Engineering Technology

Universiti Tun Hussein Onn Malaysia

86400 Batu Pahat, Johor Darul Takzim

Malaysia

Sohif Mat

Solar Energy Research Institute

Universiti Kebangsaan Malaysia 43600 Bangi, Selangor Darul Ehsan Malaysia

Khairiah Haji Badri*

Faculty of Science and Technology

Universiti Kebangsaan Malaysia

43600 Bangi, Selangor Darul Ehsan

Malaysia

Muhammad Fauzi Mohd Zain

Faculty of Engineering and Built Environment

Universiti Kebangsaan Malaysia

43600 Bangi, Selangor Darul Ehsan

Malaysia

*Corresponding author; email: kaybadri@ukm.edu.my

Received: 15 January 2014

Accepted: 15 November 2014 